\title{
Risk factors associated with portal vein thrombosis in liver cirrhosis: A case-control study
}

\author{
Nadinskaia M. Yu., Kodzoeva Kh. B., Ulyanova K. A., Rogacheva S. I., Volkova A. S., Dekhanov A. S., Strelkova D. A., \\ Ivashkin V. T.
}

Sechenov First Moscow State Medical University (Sechenov University)

Department of Internal Medicine Propaedeutics, Gastroenterology and Hepatology

8/2 Trubetskaya st., Moscow, 119991, Russian Federation

\begin{abstract}
Background. Portal vein thrombosis (PVT) in patients with liver cirrhosis is a common complication associated with adverse outcomes. The aim of the study was to build a predictive model for PVT in cirrhotic patients.

Materials and methods. A single centre case-control study was carried out. From the database of 1512 cirrhotic patients 94 with newly diagnosed PVT based on contrast-enhanced computed tomography were referred to the Case group. Malignant PVT was an exclusion criterion. Patients without PVT were stratified and matched according to sex, age and etiology of cirrhosis; case-control ratio was $1: 3-4$. The prevalence of PVT in the database, clinical, laboratory, instrumental parameters of the groups were evaluated. Logistic regression model was used to estimate association between variables and PVT.

Results. The overall prevalence of PVT was $6.2 \%$ with the highest rates among the patients with HBV infection $-16.7 \%$, nonalcoholic steatohepatitis $-15.6 \%$, alcohol abuse in combination with HCV infection $-11.7 \%$. The best predictive model included variables: ChildPugh classes B-C (coefficient of regression $\beta=1.853, p=0.001$ ), ascites $(\beta=0.460, p=0.003$ ), hepatocellular carcinoma without vascular invasion $(\beta=2.126, p=0.0001)$, endoscopic band ligation $(\beta=0.774, p=0.003)$, transabdominal esophagogastric devascularization procedure $(\beta=2.734, p=0.001)$, portal hypertensive gastropathy $(\beta=0.793, p=0.017)$, portal vein diameter $(\beta=0.203, p=0.004)$, and local factors $-\mathrm{ul}$ cerative colitis flare, Clostridium difficile enterocolitis, spontaneous bacterial peritonitis, colorectal cancer, splenectomy, cholecystectomy $(\beta=2.075, p=0.017)$. The model had accuracy $85.8 \%(95 \% \mathrm{Cl} 81.7-89.4 \%)$, sensitivity $-55.1 \%(95 \% \mathrm{Cl} 43.4-66.4 \%)$, specificity - $95 \%$ (95\% Cl 91.6-97.3\%), and AUC - 0.871 (95\% Cl 0.826-0.916).

Conclusion. Child-Pugh classes B-C, severe portal hypertension, hepatocellular carcinoma without vascular invasion, and local factors were estimated as risk factors of PVT in cirrhotic patients.

Keywords: portal vein thrombosis, liver cirrhosis, case-control study, Child-Pugh class, portal hypertension, hepatocellular carcinoma, local factors, logistic regression model

For Citation: Nadinskaia M.Yu., Kodzoeva Kh.B., Ulyanova K.A., Rogacheva S.I., Volkova A.S., Dekhanov A.S., Strelkova D.A., Ivashkin V.T. Risk factors associated with portal vein thrombosis in liver cirrhosis: A case-control study. Therapeutic Archive. 2019; 91 (2): 73-81. DOI: 10.26442/00403660.2019.02.000153
\end{abstract}

\section{Факторы риска, ассоциированные с тромбозом воротной вены, у больных циррозом печени: исследование случай-контроль}

М.Ю. Надинская, Х.Б. Кодзоева, К.А. Ульянова, А.С. Волкова, С.И. Рогачева, А.С. Аеханов, А.А. Стрелкова, В.Т. Ивашкин

ФГАОУ ВО «Первый Московский государственный медицинский университет им. И.М. Сеченова» Минздрава России (Сеченовский Университет), Москва, Россия

\begin{abstract}
Резюме
Тромбоз воротной вены (ТВВ) у больных циррозом печени (ЦП) - частое осложнение, ассоциированное с развитием неблагоприятных исходов.

Шель исслеАования - построить предиктивную модель ТВВ у больных ЦП.

Материалы и методы. Проведено одноцентровое исследование случай-контроль. Из базы Аанных 1512 больных ШП в группу «Случай» вк^ючено 94 пациента с впервые диагностированным ТВВ на основании Аанных мультиспиральной компьютерной томографии с контрастным усилением. Критерий иск^ючения - опухолевый ТВВ. Группа «Контроль» подобрана из больных без ТВВ метоАОм стратифицированной рандомизации по полу, возрасту и этиологии ЦП; отношение случай-контроль составило $1: 3-4$. Оценена частота ТВВ в общей базе Аанных, клинические, лабораторные и инструментальные параметры в группах. А^я оценки ассоциации межАу переменными и ТВВ использовалась моцель логистической регрессии.

Результаты и обсуждение. Обшая частота TBB составила 6,2\%, с наибольшими значениями среди пациентов с HBV-инфекцией $16,7 \%$, неалкогольным стеатогепатитом - 15,6\%, злоупотреблением алкоголем в сочетании с HCV инфекцией - 11,7\%. ^учшая преАиктивная модель включала в себя следуюшие переменные: Child-Pugh классов B-C (коэфрициент регрессии $\beta=1,853, p=0,001$ ), асцит $(\beta=0,460, p=0,003)$, не инвазируюший сосуды гепатоцемююлярный рак $(\beta=2,126, p=0,0001)$, эндоскопическое ^игирование $(\beta=0,774, p=0,003)$, азигопортальное разобщение $(\beta=2,734, p=0,001)$, портальную гипертензионную гастропатию $(\beta=0,793$, $p=0,017)$, Аиаметр воротной вены ( $\beta=0,203, p=0,004)$, локальные фракторы - обострение неспецифического язвенного колита, энтероколит, вызванный Clostridium difficile, спонтанный бактериальный перитонит, колоректальный рак, спленэктомию, холецистэктомию $(\beta=2,075, p=0,017)$. Точность модели составила 85,8\% (95\% $\Delta И 81,7-89,4 \%)$, чувствительность - 55, $1 \%$ (95\% $\Delta$ ㄴ 43,4-66,4\%), специфичность - 95\% (95\% $\Delta И 91,6-97,3 \%)$, плошадь под кривой - 0,871 (95\% $\Delta И 0,826-0,916)$.

Заключение. Тяжесть ЦП классов В-С по Child-Pugh, выраженная портальная гипертензия, гепатоцемлюлярный рак, не инвазируюший сосуды, и локальные факторы установлены как предикторы ТВВ у больных ШП.
\end{abstract}

КАючевые слова: тромбоз воротной вены, цирроз печени, исследование случай-контроль, класс по Child-Pugh, портальная гипертензия, гепатоцемююярный рак, локальные факторы, модель Аогистической регрессии.

Аия цитирования: Нацинская М.Ю., Коцзоева Х.Б., УАьянова К.А. и Ар. Факторы риска, ассоциированные с тромбозом воротной вены, у больных циррозом печени: исследование случай-контроль. Терапевтический архив. $2019 ; 91$ (2): $73-81$. DOI: 10.26442/00403660.2019.02.000153 
95\% CI - 95\% confidence intervals

APTT - activated partial thromboplastin time

AUC - area under the curve

CT - computed tomography

EV and GV - esophageal and gastric varices

EVL - endoscopic variceal ligation

$\mathrm{HCC}$ - hepatocellular carcinoma

IAC - International Ascites Club

INR - international normalized ratio

LS - liver stiffness
MR - magnetic resonance

NASH - non-alcoholic steatohepatitis

NLR - neutrophil-to-lymphocyte ratio

$\mathrm{OR}$ - odds ratios

$\mathrm{PH}$ - portal hypertension

PHG - portal hypertensive gastropathy

PVT - portal vein thrombosis

ROC - receiver operating curve

$\mathrm{SBP}$ - spontaneous bacterial peritonitis

$\mathrm{UC}$ - ulcerative colitis
Portal vein thrombosis (PVT) was first diagnosed by eminent Russian physician Botkin S.P. in 1862 [1]. After six years, two Scottish physicians, Balfour G.W. and Stewart T.G., described the cavernous transformation of the portal vein as a result of PVT [2].

PVT is an unusual site thrombosis with low incidence and prevalence rates in the general population, estimated to be 0.7 and 3.7 per 100,000 persons, respectively [3]. However, the frequency of PVT is substantially higher in patients with cirrhosis, varied between 0.6 and $26 \%$, according to the evaluation test and patient population [4].

The main pathogenic factors of PVT in cirrhosis are portal hypertension and the decreased portal flow resulting from structural liver damage. A procoagulant imbalance may also play a role due to reduced synthesis of natural inhibitors of coagulation such as protein $\mathrm{C}$, protein $\mathrm{S}$, and antithrombin III levels combined with normal or increased levels of factor VIII [5].

PVT in cirrhosis is associated with higher mortality rate, increased risk of acute renal failure and hepatorenal syndrome, bowel ischemia due to extension of thrombosis to the superior mesenteric vein, greater operative technical difficulties during liver transplantation, and worse liver transplantation outcomes [6-8]. Baveno VI Consensus Workshop determined identification of risk factors for PVT in cirrhosis to be of key importance in research the agenda [9].

The well-known risk factors of PVT are severe cirrhosis according to the Child-Pugh score and portal flow velocity $<15 \mathrm{~cm} / \mathrm{sec}$. The role of cirrhosis etiology, inherited thrombophilia, clinical features of portal hypertension, treated varices, and comorbidities in PVT development remains controversial [10-12].

In the case-control study, we aimed to build a predictive model for the risk of PVT in cirrhotic patients.

\section{Materials and methods}

The study was approved by the local Ethical Committee (15.05.2013, ref: 05-13).

\section{Database}

To conduct the study, an electronic database was created. It was based on the available primary medical documentation

\section{Information about authors}

Maria Yu. Nadinskaia, Ph.D in Medicine, Associate Professor at the Department of Internal Medicine Propaedeutics, Gastroenterology and Hepatology at Sechenov First Moscow State Medical University (Sechenov University)http://orcid.org/0000-0002-1210-2528, Scopus Author ID 6507949442

Khava B. Kodzoeva, Kseniya A. Ulyanova, Sofia I. Rogacheva, Alina S. Volkova, Artem S. Dekhanov A.S., Daria A. Strelkova D. are students of Sechenov University

Vladimir T. Ivashkin, MD, RAS Academician, Professor, Head at the Department of Internal Medicine Propaedeutics, Gastroenterology and Hepatology at Sechenov First Moscow State Medical University (Sechenov University), Scopus Author ID: 57201595785 and consisted of clinical data and laboratory/instrumental of patients with liver cirrhosis over 18 years of age. The disease was confirmed by standard diagnostic criteria. All patients were admitted to Clinic of Internal Propedeutics, Gastroenterology, and Hepatology from January 1, 2006 to December 31,2015 . The database contained of 1512 cirrhotic patients of different etiology; the mean follow-up was 15 months.

\section{Case and Control Selection}

We evaluated all patients in the database to determine the presence or absence of PVT (Fig 1).

The Case group comprised of patients with newly diagnosed PVT confirmed by contrast-enhanced computed tomography $(\mathrm{CT})$ scan.

PVT was defined as a thrombus of the portal vein trunk and/or lobar branches or cavernous transformation of the portal vein [13]. Four patients with portal vein invasion from hepatocellular carcinoma (HCC) were excluded. A total of 94 patients found to be eligible for inclusion in the Case group, 52 males and 42 females, aged 28 to 80 years. The most common causes of cirrhosis were chronic infection with viral hepatitis and/or alcohol consumption $(77 \%)$, followed by autoimmune hepatitis and non-alcoholic steatohepatitis (NASH) $-11 \%$.

We confirmed the absence of the thrombus based on the doppler ultrasound data, CT, and magnetic resonance (MR) imaging in the other 1414 patients. Cases with PVT were matched 1:3-4 by sex, age and etiology of liver disease using stratified randomly sampling to the corresponding Controls with cirrhosis but no PVT.

\section{Analyzed data}

We evaluated the general frequency of PVT as well as the frequency according to the etiology of cirrhosis (the last was calculated as the ratio of the number of cirrhotic patients of certain etiology with PVT to the number of all cirrhotic patients of this etiology). Cases were compared to Controls for the onset and progression of portal hypertension, severity of cirrhosis, laboratory values, imaging, and presence of comorbidities or local factors. Analyzed laboratory and imaging data preceded the PVT onset by $3[1 ; 4]$ months, on average.

The grade of ascites and the presence of dilutional hyponatremia were defined according to the International Ascites Club (IAC) criteria, European Association for the Study of the Liver criteria, and Russian Scientific Liver Society guidelines $[14,15]$. Hepatic encephalopathy was diagnosed and graded clinically according to the West Haven criteria.

\section{Corresponding Author:}

Maria Yu. Nadinskaia, Ph.D in Medicine, Associate Professor at the Department of Internal Medicine Propaedeutics, Gastroenterology and Hepatology at Sechenov First Moscow State Medical University (Sechenov University)

Address: 8/2 Trubetskaya Street, Moscow, 119991, Russia

E-mail: marianad@rambler.ru 


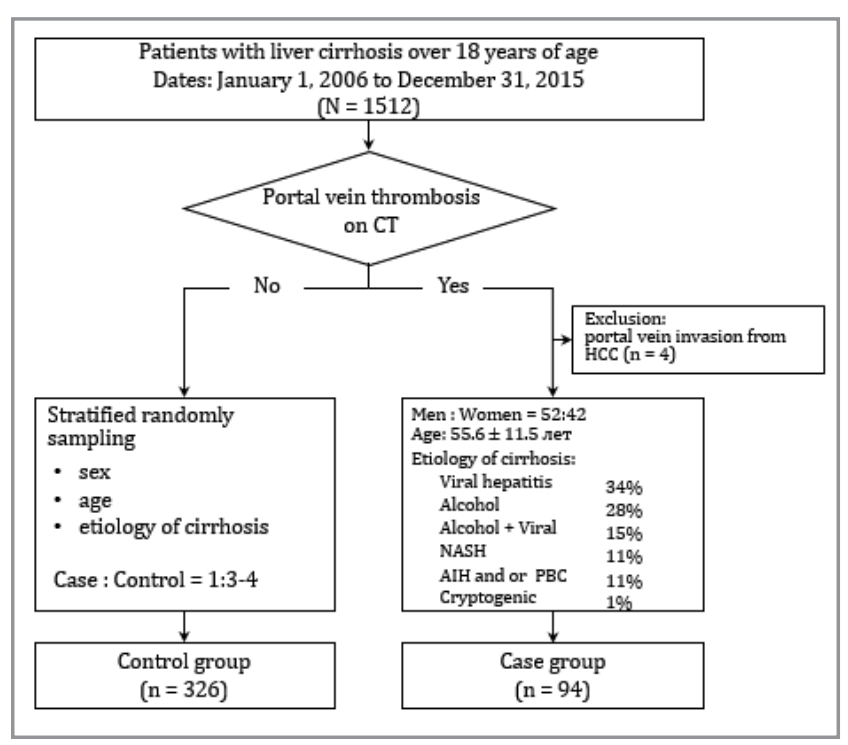

Figure 1. Flowchart of the patient enrollment process of study.

Child-Pugh, MELD, and MELD-Na scores were used to assess the severity of liver disease. The size of esophageal and gastric varices (EV and GV) was classified according to the Guidelines on the Management of Variceal Hemorrhage of the Russian Society of Surgeons (Grade 1, 2-3mm, Grade 2, 4-5 $\mathrm{mm}$, Grade 3,>5mm) [16]. The portal vein diameter and the spleen length were measured via Doppler ultrasound. Liver stiffness (LS) measurement was performed by transient elastography using FibroScan (Echosens, Paris, France). HCC without portal vein trunk and branches invasion was diagnosed by contrast-enhanced CT or MR imaging; the tumor size was more than $2 \mathrm{~cm}$ with typical vascularization patterns in all patients.

\section{Statistical analysis}

A two steps sequential analysis was performed. In the first step, a univariable analysis was carried out to compare Cases to Controls for all available data. The normality of the distribution was tested using Kolmogorov-Smirnov, Shapiro-Wilk, and Cramer-von Mises tests. The distribution of most of the variables was significantly different from the normal distribution.

Descriptive statistics were calculated, including median with interquartile range [25th-75th percentile] or mean with standard deviation. Categorical variables were expressed as counts and percentages. The percentage of missing values was also calculated in each group as a ratio of patients with missing values to the overall number of patients in the group. Comparisons between groups were made by Mann-Whitney U-test and independent t-test. For categorical variables, chi-square test and Fisher's exact test were used. From the two-way tables, Odds Ratios (OR) and corresponding 95\% confidence intervals $(95 \% \mathrm{CI})$ were calculated. The level of significance was set at $p<0.05$.

In the second step, the logistic regression model was built to assess a statistical relationship between the outcome (PVT) and continuous and categorical variables [17]. All the variables significant in the univariable analysis were entered into a logistic regression with a forward and backward elimination procedure; only variables with less than $20 \%$ missing data in each group were imputed. This analysis aimed to determine combinations of categorical and continuous variables that best discriminate between Cases and Controls. The diagnostic performance of the logistic regression equations was measured by the coefficients ( $\beta$ values), accuracy, sensitivity, and specificity.

Thus, we selected a total of ten equations with the highest accuracy out of 40. Receiver operating curve (ROC) analysis was employed, and the area under the curve (AUC) was calculated to evaluate the predictive model specificity and sensitivity; the comparison of AUCs was based on Delong's method. Statistical analysis and graphic design were done using the statistical packages such as Microsoft Excel 2016 (Microsoft Corporation, Redmond, WA, USA), Statistica v.10.0 (StatSoft Inc., Tulsa, USA), IBM SPSS v.22.0 (IBM-SPSS, Chicago, Illinois, USA)), and MedCalc v.16.8.4 (MedCalc Software Inc., Broekstraat, Belgium).

\section{RESULTS}

Prevalence of PVT. The overall prevalence of PVT was $6.2 \%$, greatly varying according to the underlying liver disease; a higher rate was seen in patients with chronic infection hepatitis B virus $(16.7 \%)$ and NASH $(15.6 \%)$ while alcoholic liver disease with or without hepatitis $\mathrm{C}$ virus $(7.8 \%)$, hepatitis $\mathrm{C}$ virus $(6.7 \%)$, autoimmune hepatitis $(5.1 \%)$, primary biliary cholangitis $(2 \%)$, overlap syndrome $(1.1 \%)$, and cryptogenic cirrhosis $(0.8 \%)$ were less frequent (Fig. 2).

\section{Comparison between the groups}

Onset and progression of portal hypertension. EV was the first clinical presentation of portal hypertension in $68-74 \%$ of patients in both groups, increasing by $14 \%$ during observation. Ascites and variceal hemorrhage as the initial presentations of portal hypertension were significantly more often reported in the Case group (Table 1).

The portal hypertension duration was almost two times longer in Case group. In both groups, the number of patients with a history of variceal hemorrhage increased slightly between portal hypertension onset and inclusion in the study. The OR for the history of variceal hemorrhage was 1.9 [95\% CI, 1.1-3.4; Fig. 3); rebleeding rates did not differ between groups.

The rates of prophylaxis and treatment of variceal bleeding with endoscopic variceal ligation (EVL) or transabdominal esophagogastric devascularization procedure, were three times higher in PVT patients (Table 1) being much higher for EVL than devascularization procedure (Fig. 3).

Repeated EVL to variceal eradication was more often required in the Case group. Previous sclerotherapy and surgical shunts had similar prevalence in the PVT and non-PVT groups; both procedures were rarely performed.

The proportion of patients with refractory ascites, grade 3 $\mathrm{EV}$, presence of $\mathrm{GV}$ and portal hypertensive gastropathy (PHG) was greater in the Case group. The medians of the other portal hypertension features, such as portal vein diameter and spleen length, were also significantly higher in PVT patients (Table 1).

The severity of cirrhosis. Cases had a poorer prognosis of cirrhosis than Controls: most patients with PVT were classified as Child-Pugh B-C and had significantly higher MELD and MELD-Na scores (Table 1). The OR for Child-Pugh B-C was 7.2 [95\%, CI 3.3-14.9] (Fig. 3). There were no significant differences regarding the presence and stage of hepatic encephalopathy in Cases and Controls.

Laboratory and imaging variables. Red blood cell count (3.73 \pm 0.06 million cells per $\mathrm{mcL}$ in Cases vs. 3.96 \pm 0.04 million cells per mcL in Controls), absolute lymphocyte count, and hemoglobin level were lower in the Case group. Leucocyte and platelet counts did not differ between groups, while the neutrophil-to-lymphocyte ratio (NLR) was significantly higher in PVT patients (Table 1). 
Table 1. Basic clinical and laboratory and imaging characteristics of patients in Case and Control groups

\begin{tabular}{|c|c|c|c|c|}
\hline Characteristics & $\begin{array}{l}\text { Case } \\
\mathrm{N}=94\end{array}$ & $\begin{array}{l}\text { Control } \\
\mathrm{N}=326\end{array}$ & p-value & $\begin{array}{l}\text { Missing data, \% } \\
\text { Case I Control }\end{array}$ \\
\hline \multicolumn{5}{|l|}{ Onset of portal hypertension } \\
\hline Ascites, n (\%) & $54(57,4 \%)$ & $140(42,9 \%)$ & 0,013 & $-*$ \\
\hline $\mathrm{EV}, \mathrm{n}(\%)$ & $70(74,5 \%)$ & $222(68,1 \%)$ & 0,238 & - \\
\hline Variceal bleeding, $\mathrm{n}(\%)$ & $17(18,1 \%)$ & $33(10,1 \%)$ & 0,036 & - \\
\hline Duration of portal hypertension, months & $15,5[5 ; 45]$ & $8[0 ; 29]$ & 0,001 & - \\
\hline Progression of portal hypertension & & & & - \\
\hline Ascites, grade 3, n (\%) & $33(35,1 \%)$ & $38(11,7 \%)$ & $<0,00001$ & - \\
\hline $\mathrm{EV}, \mathrm{n}(\%)$ & $83(88,3 \%)$ & $270(82,8 \%)$ & 0,202 & $2,1 \mid 2,5$ \\
\hline $\mathrm{EV}$, grade $3, \mathrm{n}(\%)$ & $52(55,3 \%)$ & $138(42,3 \%)$ & 0,026 & $2,1 \mid 2,5$ \\
\hline $\mathrm{GV}, \mathrm{n}(\%)$ & $13(13,8 \%)$ & $17(5,2 \%)$ & 0,005 & $2,1 \mid 2,5$ \\
\hline PHG, n (\%) & $49(52,1 \%)$ & $115(35,3 \%)$ & 0,005 & $2,1 \mid 2,5$ \\
\hline Variceal bleeding, $\mathrm{n}(\%)$ & $22(23,4 \%)$ & $45(13,8 \%)$ & 0,025 & - \\
\hline All treatments for variceal bleeding, $\mathrm{n}(\%)$ & $27(28,7 \%)$ & $39(11,9 \%)$ & 0,00008 & - \\
\hline $\mathrm{EVL}, \mathrm{n}(\%)$ & $25(26,6 \%)$ & $36(11,0 \%)$ & 0,0002 & - \\
\hline $\begin{array}{l}\text { Transabdominal esophagogastric } \\
\text { devascularization procedure, } \mathrm{n}(\%)\end{array}$ & $9(9,6 \%)$ & $3(0,9 \%)$ & $<0,00001$ & - \\
\hline Spleen length, $\mathrm{cm}$ & $15,7[14,3 ; 18,4]$ & $14,5[12,8 ; 16,5]$ & 0,001 & $19,1 \mid 13,5$ \\
\hline Portal vein diameter, $\mathrm{mm}$ & $13,9[11,7 ; 15,9]$ & $12,2[11,0 ; 13,6]$ & 0,0001 & $15,9 \mid 16,3$ \\
\hline \multicolumn{5}{|l|}{ Severity of cirrhosis } \\
\hline Child-Pugh B-C, n (\%) & $85(90,4 \%)$ & $178(54,6 \%)$ & $<0,00001$ & $-13,7$ \\
\hline MELD & $12,8[10,3 ; 15,7]$ & $11,1[9,3 ; 14,1]$ & 0,005 & $15,9 \mid 15,0$ \\
\hline MELD-Na & $14,5[11,2 ; 17,5]$ & $11,6[9,5 ; 15,5]$ & 0,002 & $23,4 \mid 29,8$ \\
\hline Hemoglobin, g/l & $117,2[99,9 ; 133,7]$ & $127,9[112,9 ; 139,1]$ & 0,001 & $2,1 \mid 1,8$ \\
\hline Lymphocytes, $\times 10^{9} / \mathrm{L}$ & $1,04[0,64 ; 1,57]$ & $1,45[0,98 ; 1,92]$ & 0,001 & $4,3 \mid 2,5$ \\
\hline NLR & $2,5[1,8 ; 3,6]$ & $1,8[1,4 ; 2,6]$ & 0,001 & $4,3 \mid 2,5$ \\
\hline Platelets, $\times 10^{9} / \mathrm{L}$ & $87,5[62,6 ; 137,1]$ & $98,6[68,2 ; 143,3]$ & 0,227 & $4,3 \mid 2,5$ \\
\hline Albumin, $g / L$ & $30,0[26,6 ; 34,0]$ & $34,0[29,0 ; 37,7]$ & 0,001 & - \\
\hline Total bilirubin, $\mu \mathrm{mol} / \mathrm{l}$ & $34,0[22,6 ; 58,1]$ & $32,5[20,5 ; 53,0]$ & 0,177 & - \\
\hline $\mathrm{Na}, \mathrm{mmol} / \mathrm{l}$ & $137,4[134,8 ; 140,2]$ & $139,5[136,1 ; 142,3]$ & 0,002 & $18,1 \mid 11,7$ \\
\hline APTT Ratio & $1,2[1,1 ; 1,3]$ & $1,2[1,0 ; 1,3]$ & 0,615 & $19,1 \mid 16,3$ \\
\hline INR & $1,26[1,14 ; 1,43]$ & $1,17[1,09 ; 1,31]$ & 0,001 & $-13,4$ \\
\hline Fibrinogen, $g / 1$ & $2,68[2,04 ; 3,52]$ & $2,71[2,12 ; 3,48]$ & 0,784 & $19,1 \mid 16,3$ \\
\hline $\mathrm{HCC}$ without portal vein invasion, $\mathrm{n}(\%)$ & $21(22,3 \%)$ & $15(4,6 \%)$ & $<0,00001$ & - \\
\hline
\end{tabular}

-* no missed data

There were no significant differences in alanine aminotransferase, aspartate aminotransferase, $\gamma$-glutamyl transpeptidase, and total bilirubin. PVT patients had lower albumin and cholinesterase (2665 [1759; 4404] U/L vs. 4075 [2820; 5942] $\mathrm{U} / \mathrm{L}$, reference ranges 5860 - $11800 \mathrm{U} / \mathrm{L}$ ) levels, reflecting impaired liver function; although, only half of the patients in both groups had known cholinesterase levels.

Activated Partial Thromboplastin Time (APTT) and fibrinogen values were in reference ranges and did not differ between groups. PVT was associated with an elevated international normalized ratio (INR) (Table 1).

The D-dimer level was analyzed in 17 PVT patients: 12 patients exceeded the upper limit of the normal by $2-15$ times. In the Control group, D-dimer was measured in four patients found to be increased in all of them by 1.5-2 times.

Levels of total protein, glucose, urea, potassium, lipids, Immunoglobulins A, M, and G, as well as the distribution of the $\mathrm{ABO}$ and $\mathrm{Rh}$ blood group, were similar between the Cases and the Controls.
Creatinine levels did not differentiate between the two groups. The sodium level was significantly lower in PVT patients (Table 1). PVT trended to associate with dilutional hyponatremia $(p=0.062)$. C-reactive protein was observed in almost half Cases and Controls being significantly higher in PVT patients $(6.8[0 ; 19.5] \mathrm{mg} / \mathrm{l}$ vs. $0[0 ; 6.4] \mathrm{mg} / \mathrm{l}, p=0.0001$, reference range $<5 \mathrm{mg} / \mathrm{l})$.

LS was evaluated in $14 \%$ of patients with PVT and $11 \%$ of patients without PVT. The median LS value was 42.7 [22.6; $67.2] \mathrm{kPa}$ in Case group and 29.0 [26.3; 33.7] in Control group $(p=0.041)$.

Comorbidities. No differences were observed in frequency, severity, and duration of comorbidities such as diabetes mellites, essential hypertension, and ischemic heart disease. Patients with PVT had a higher prevalence of HCC without portal vein invasion (Table 1) - the OR for HCC was about six times higher for Cases (Fig. 3). Thrombosis was mostly (in 17 cases out of 21) localized in the portal vein trunk; isolated portal vein branches thrombosis was rarely observed, seen ipsilateral to 


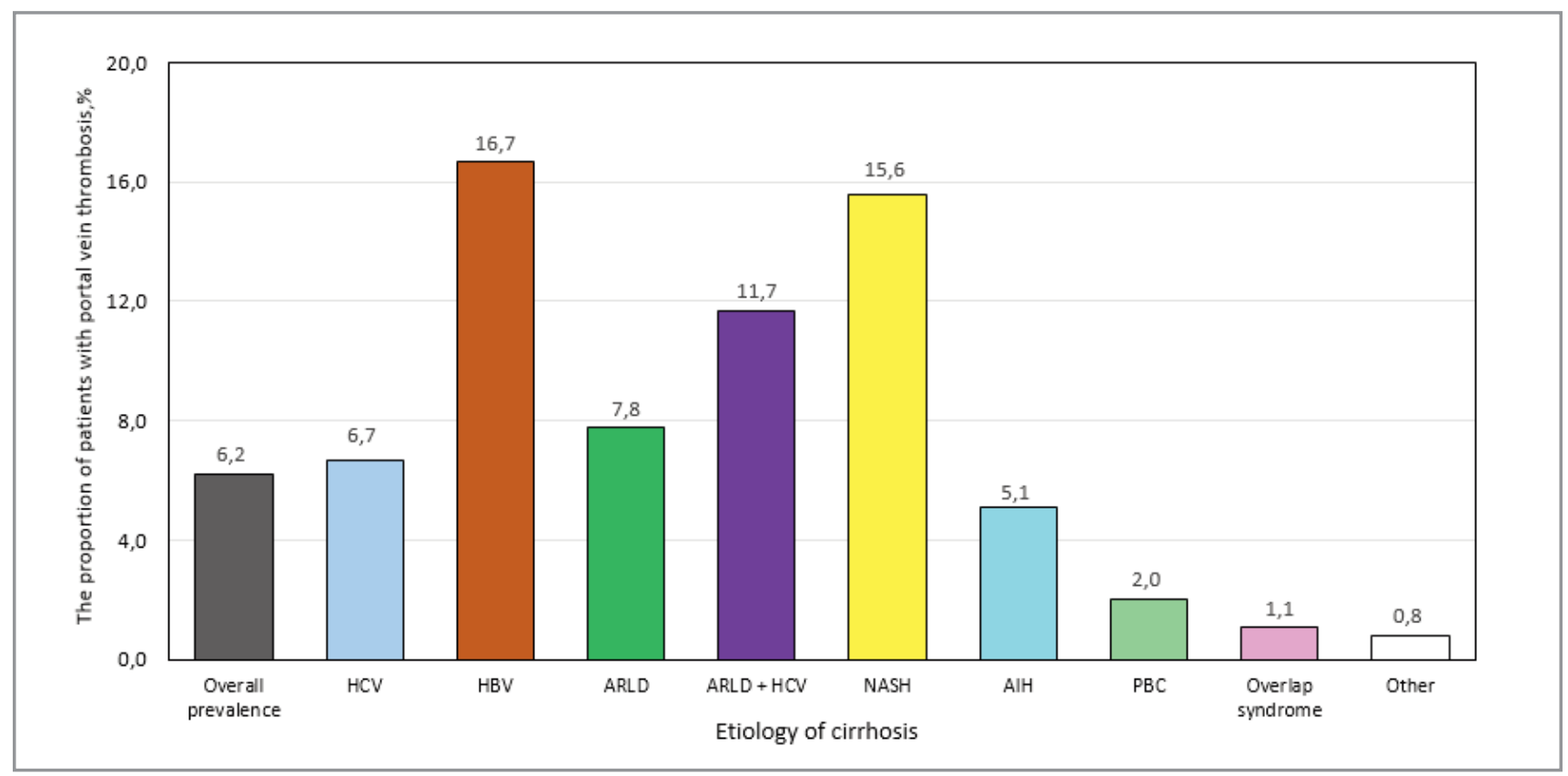

Figure 2. The overall prevalence of portal vein thrombosis and depending on the etiology of cirrhosis.

HBV - Hepatitis B virus; HCV - Hepatitis C virus; ARLD - Alcohol-Related Liver Disease; NASH - Non-Alcoholic Steatohepatitis; AIH - Autoimmune Hepatitis; PBC - Primary Biliary Cholangitis; Overlap syndrome: AIH + PBC, AIH +HCV, AIH + Primary Sclerosing Cholangitis; Other: Wilson disease, Hereditary Hemochromatosis, Cryptogenic cirrhosis

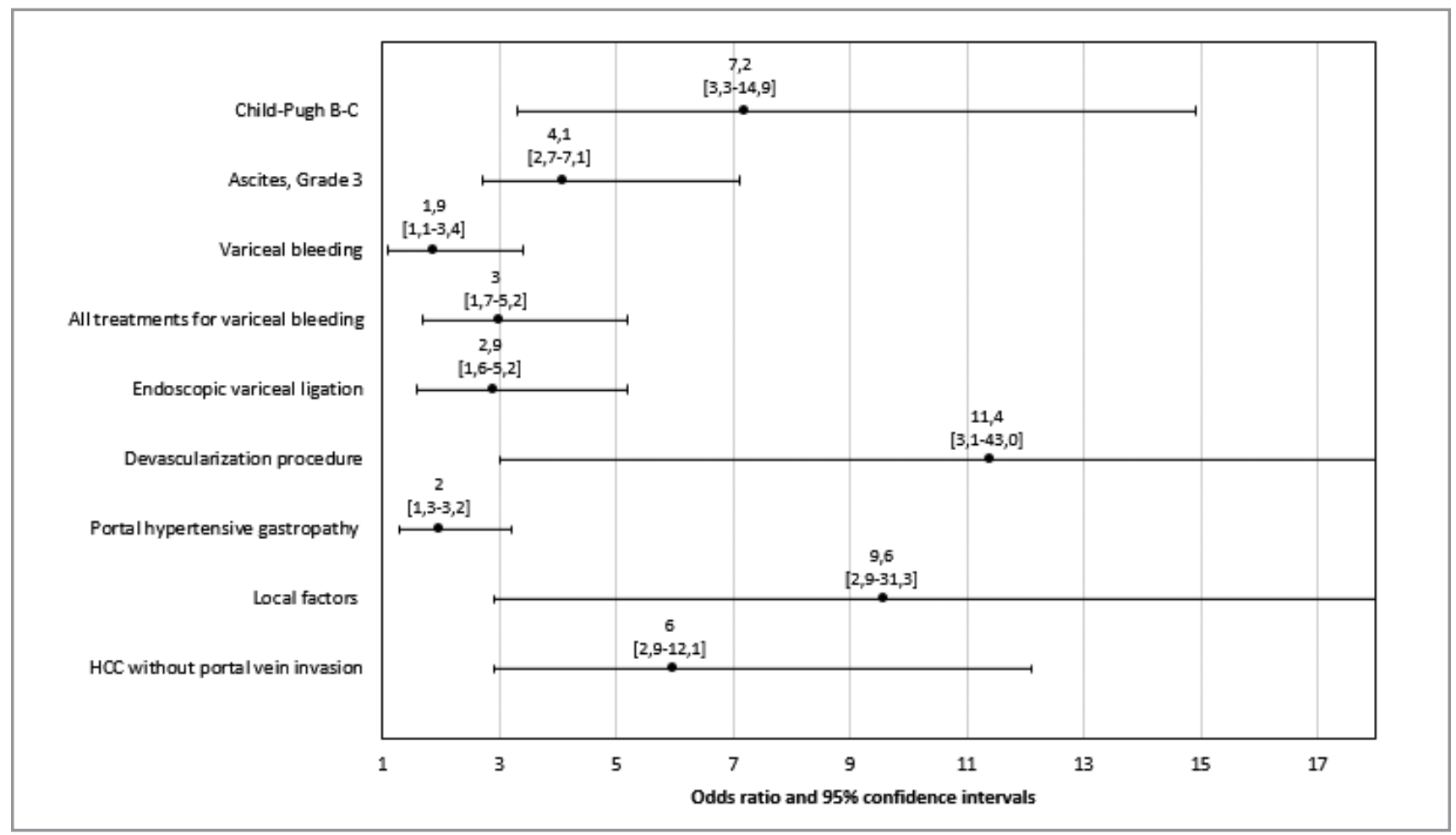

Figure 3. The odds ratio and $95 \%$ confidence intervals for clinical, laboratory, and imaging features

the tumor in three patients, and contralateral to the tumor in one patient.

Relative to non-HCC patients, HCC patients more often had completely occlusive PVT $(p=0.00026)$ and other venous thrombosis located in the hepatic veins or inferior vena cava $(p=0.038)$.

Local factors. Such local factors as ulcerative colitis, Clostridium difficile infection, spontaneous bacterial peritoni- tis (SBP), and abdominal blunt trauma were considered as possible risk factors for PVT only if PVT was absent (according to ultrasound data, contrast-enhanced CT, or MR imaging) before the factors were diagnosed; the duration of these conditions was limited to three months prior to study entry.

In the PVT group, two patients had ulcerative colitis (UC) flare, and one had C. difficile enterocolitis while only one patient presented with UC flare in the Control group $(p=0.012)$. 
Table 2. Estimation results of the logistic regression models

\begin{tabular}{|c|c|c|c|c|c|c|c|c|c|c|}
\hline \multirow{3}{*}{ Variable } & \multicolumn{10}{|c|}{ Model numbers } \\
\hline & 1 & 2 & 3 & 4 & 5 & 6 & 7 & 8 & 9 & 10 \\
\hline & \multicolumn{10}{|c|}{ Coefficient of regression $\beta$} \\
\hline Child-Pugh B-C & 1,853 & 2,434 & & 1,748 & 1,744 & & 1,419 & & & \\
\hline Ascites, grade 1-3 & 0,460 & & 0,731 & 0,528 & 0,507 & 0,781 & 0,364 & & & \\
\hline HCC without portal vein invasion & 2,126 & 2,290 & 2,033 & & 2,046 & & 1,468 & & & \\
\hline EVL, number of procedures & 0,774 & 0,844 & 0,646 & 0,725 & 0,785 & 0,613 & & 0,691 & & \\
\hline $\begin{array}{l}\text { Transabdominal esophagogastric } \\
\text { devascularization procedure }\end{array}$ & 2,734 & 2,378 & 3,073 & 2,820 & 2,690 & 3,198 & & 2,540 & & \\
\hline PHG & 0,793 & 0,813 & 0,842 & 0,767 & 0,681 & 0,821 & & 0,663 & & \\
\hline Portal vein diameter, $\mathrm{mm}$ & 0,203 & 0,198 & 0,221 & 0,207 & 0,214 & 0,226 & & 0,240 & & \\
\hline Local factor (any of all) & 2,075 & 2,415 & 1,942 & 1,840 & & 1,717 & 2,129 & & & \\
\hline Hemoglobin, g/l & & & & & & & & & & $-0,021$ \\
\hline Lymphocytes, $\times 10^{9} / \mathrm{L}$ & & & & & & & & & $-0,638$ & \\
\hline NLR & & & & & & & & & & 0,081 \\
\hline Albumen, $\mathrm{g} / \mathrm{L}$ & & & & & & & & & $-0,056$ & \\
\hline \multirow[t]{2}{*}{ INR } & & & & & & & & & 1,299 & \\
\hline & \multicolumn{10}{|c|}{ Operating characteristics } \\
\hline Diagnostic accuracy, $\%$ & 85,8 & 83,2 & 85,3 & 83,8 & 84,4 & 83,6 & 79,9 & 81 & 76,8 & 80,3 \\
\hline Sensitivity, $\%$ & 55,1 & 47,4 & 48,7 & 46,2 & 50 & 44,9 & 25,5 & 24,4 & 5,6 & 7,2 \\
\hline Specificity, \% & 95,0 & 93,9 & 95,9 & 95,0 & 94,6 & 94,8 & 96,2 & 97,4 & 97,7 & 99,4 \\
\hline AUC & 0,871 & 0,854 & 0,847 & 0,847 & 0,861 & 0,822 & 0,825 & 0,716 & 0,694 & 0,647 \\
\hline
\end{tabular}

SBP was diagnosed in four Cases and three Controls $(p=0.027)$.

For one patient, non-metastatic colorectal cancer was diagnosed at the same time as PVT. Only PVT patients underwent surgeries such as splenectomy and cholecystectomy; of these, one underwent splenectomy, and three underwent cholecystectomy. Cholecystectomy was performed for acute cholecystitis in one patient; in other cases, cholecystectomy was done during the transabdominal esophagogastric devascularization procedure. One patient in the Case group and two patients in the Control group had abdominal blunt trauma required hospitalization.

Patients with PVT had 9.6 times more chance to have even one local factor such as UC flare, C. difficile enterocolitis, SBP, colorectal cancer, splenectomy cholecystectomy for acute cholecystitis compared to non-PVT patients (Fig. 3).

We also considered a possible predictor of a preoperative administration of high-dose platelet transfusions a month before study entry in the patient underwent radical prostatectomy.

\section{Logistic regression and $R O C$ analyses}

The factors included in the best ten logistic regression models are presented in Table 2.

The highest $\beta$ coefficient values were noted for the following variables: Child-Pugh $\mathrm{B} / \mathrm{C}$, devascularization procedure, $\mathrm{HCC}$ without portal vein invasion, and local factors. The specificity in all models was $94-99 \%$, whereas the sensitivity greatly varied. The highest sensitivity of $55.1 \%$ (95\% CI, 43.4$66.4 \%$ ) was found in model \#1, including Child-Pugh B/C, the severity of ascites according to IAC, HCC without portal vein invasion, history of variceal treatment, presence of PHG, portal vein diameter, and local factors. Removing one or two factors from the model (Child-Pugh B/C, ascites, HCC, local factors) reduced the sensitivity by $5-10 \%$ (Models \#2-6).
Logistic regression equations containing either no or only variables related to portal hypertension (Models \#7 and \#8) decreased sensitivity up to $25 \%$. Models based on laboratory values alone (albumin, INR, hemoglobin, lymphocytes, and NLR) had lower sensitivity.

The highest AUC revealed for model \#1 was 0.871 (95\% CI 0.826-0.916; Fig. 4).

When pairwise comparing models 1-7, AUCs did not differ. The lowest AUCs were found for models \#8-10 (Table 2). The pairwise comparison of the AUCs was statistically significantly different between the models \#1-7 and model \#9 as well as models \#1-5 and model \#8.

\section{Discussion}

The overall prevalence of PVT in our study of cirrhotic paרtients was $6.2 \%$, which was comparable to the prevalence in other studies included thousands of participants and higher than the prevalence observed in the American largest nationally-representative database of hospital discharges consisted of more than three million discharges, which was only $1.5 \%[6,8,18]$.

The frequency of PVT was higher among patients with chronic hepatitis B infection (16.7\%), NASH (15.6\%), and alcohol consumption combined with hepatitis $\mathrm{C}$ infection (11.7\%). Cirrhosis etiology has been shown to play a role in PVT development, with PVT more likely occurring in patients with alcohol consumption and hepatitis B virus $[11,19]$. Emerging data suggest that NASH cirrhosis may be an independent risk factor for thrombotic events, including PVT $[8,18]$.

Sequential statistical analysis of clinical, laboratory, and instrumental data allowed building predictive models of PVT in cirrhotic patients eliminating the influence of age, sex, and etiology of liver disease.

The different combinations of variables, including ChildPugh A, mild portal hypertension, absence of HCC and local 


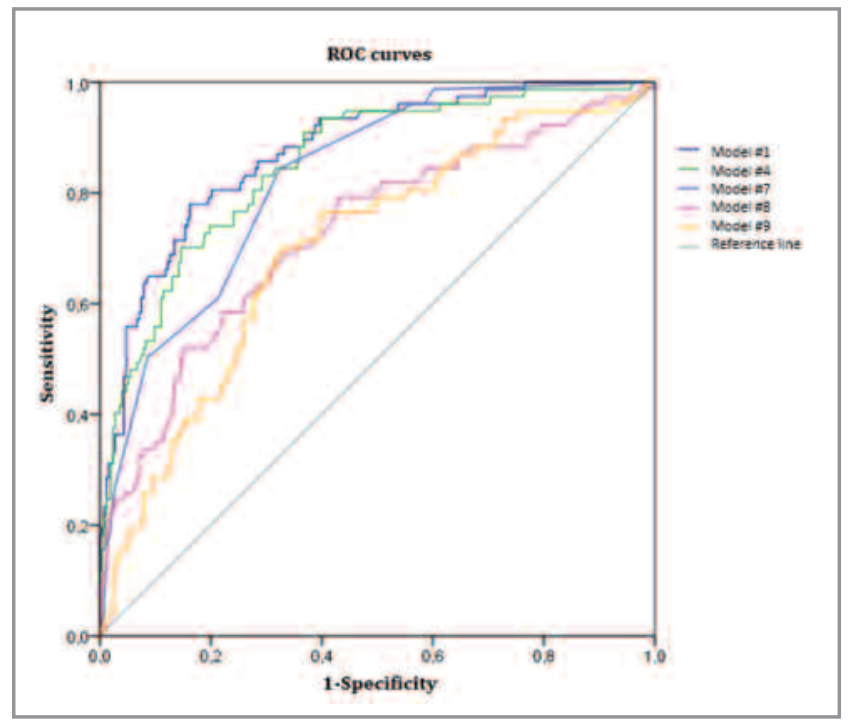

Figure 4. ROC curves from the logistic regression models

factors, normal or near-normal levels of hemoglobin, lymphocytes, neutrophil-to-lymphocyte ratio (NLR), albumin, and INR values demonstrated ability to exclude PVT.

Two main factors observed in most patients - Child-Pugh B-C and severe portal hypertension - predicted the presence of PVT best. Other less common significant predictors for PVT included HCC without portal vein invasion and local factors.

The prevalence of Child-Pugh B-C cirrhosis was about $90 \%$ in the PVT group, highlighting severe cirrhosis as an independent major risk factor [4]. Although we found the differences between three variables out of five included in ChildPugh score (severity of ascites, albumin, and prothrombin levels), only one factor - the severity of ascites - was entered in the predictive model.

The sensitivity of the models consisted of either ascites (model \#3) or Child-Pugh B-C (model \#2) with other factors being equal did not differ. However, including both predictors in the model 1 raised the sensitivity. Thus, we found severe ascites to be an independent risk factor for PVT along with Child-Pugh B-C.

In the PVT group, portal hypertension was characterized by a longer duration and more frequent presentation with ascites and varices compared to the non-PVT group. However, no differences were seen in the number of bleedings between cases and controls, which was comparable to another study [11].

Based on this, it can be assumed that PVT in patients with cirrhosis is associated not with the number, but with the fact itself of bleeding from EV, which reflects the achievement of a critical increase in pressure in the portal vein.

Accordingly, the median LS was significantly higher in the case group than in control and exceeded the threshold value for variceal bleeding in cirrhotic patients [20].

PVT patients had a greater number of variceal therapies (EVL and devascularization procedure) which on the one hand reflects more severe portal hypertension state and on the other hand may serve as an additional factor in reducing the velocity of portal vein blood flow.

Previous studies also had shown that EVL and devascularization procedure are associated with an increased prevalence of PVT $[11,21]$. Predictive models also included the other two factors related to portal hypertension: PHG and portal vein diameter.
PVT and HCC without a portal vein invasion were detected simultaneously in every fifth patient. The prevalence of benign PVT (with no vascular invasion) has been shown to be up to $73 \%$ of the total PVT in HCC patients being associated with hypercoagulable state induced by malignancy itself [22]. This systemic mechanism is confirmed by the more frequent thrombosis of the hepatic veins and inferior vena cava in PVT patients with HCC.

Local factors are represented mostly by systemic inflammation. Severe portal hypertension and refractory ascites increase bacterial translocation, which increases portal hypertension, leading to a circulus vitiosus [23]. Furthermore, endotoxin seems to enhance systemic factor VIII release from endothelial cells contributing to hypercoagulability [24]. This explains why SPB is more frequently detected in cirrhotic patients.

Although the active phase of inflammatory bowel disease is generally recognized risk factor for PVT in non-cirrhotic patients, in our study ulcerative colitis relapse was considered as a causal factor for thrombosis in cirrhotic patients [25]. We also revealed the association between PVT and C. Difficile infection which is in-line with a previous study demonstrated a higher frequency of C. Difficile infection among $\mathrm{HCC}$ patients with PVT [26].

In PVT patients, an increase in the marker of systemic inflammation, the NLR, was also noted, which in some studies was established as a predictor of survival in patients with liver cirrhosis [27].

Unlike other studies, we found no significant differences in platelet levels between groups due to the high frequency of HCC, which is known to produce thrombopoietin which promotes thrombocytosis [29]. The median platelet count in PVT patients with HCC was higher by 40,000 cells per mcL than in non-HCC patients.

The most important indicators of the coagulogram were characterized by no significant differences in APTT and fibrinogen between both groups and INR increase in patients with PVT, which once again shows the complexity of the interpretation of INR in patients with liver cirrhosis in favor of only the risk of bleeding.

We measured D-dimer level in several patients. There are contradictory findings on the role of D-dimer in predicting PVT in cirrhotic patients. However, D dimer level is significantly associated with the degree of liver dysfunction according to Child-Pugh and MELD and should be interpreted with caution in these patients [29].

Limitations. Case-control studies suffer some limitations, including susceptibility to systemic bias. However, case-control studies are an efficient method for the study of rare outcomes such as PVT because of less costly and less time-consuming [30]. The present study minimized risk of bias by careful analysis of the primary medical records, strict selection patients with newly diagnosed PVT according to well-defined criteria, randomly matching groups by sex, age and etiology of cirrhosis, and estimating missing data in predictive models.

\section{Conclusions}

Despite the high rate of hemorrhage due to a decreased level of platelets and increased level INR, cirrhosis is now considered as a prothrombotic condition. In our study, the prevalence rate for PVT was $6.2 \%$; being the highest for patients with chronic hepatitis B virus (16.7\%), NASH (15.6\%), and alcohol consumption combined with chronic hepatitis $\mathrm{C}$ infection $(11.7 \%)$.

PVT is significantly associated with Child-Pugh B-C and portal hypertension-related conditions: refractory ascites, endo- 
scopic or surgical treatment of varices, $\mathrm{PHG}$, and enlarged portal vein diameter. Other risk factors include HCC without portal vein invasion, ulcerative colitis flare, SBP, and colorectal cancer.

Predictive models had an accuracy of $84-86 \%$, high specificity of $94-99 \%$, and moderate sensitivity of $45-55 \%$ which indicates the need for further research to identify risk factors for PVT in cirrhotic patients.

\section{Authors contributions}

Maria Yu. Nadinskaia, made the major contribution to the concept of the article, organized the creation of the database, conducted statistical analysis, wrote a significant part of the text. designed the figure, approved the final version of the publication and agreed to take responsibility for all aspects of the work.

\section{REFERENCES/АИTEPATYPA}

1. Botkin SP. Krankheitsgeschichte eines Falles von Pfortaderthrombose. Archiv f. pathol. Anat. 1864;30(3):449-457. doi: 10.1007/BF02280955 [Botkin SP. Case of portal vein thrombosis. Archives of Pathological Anatomy. 1864;30(3):449-457. doi: 10.1007/BF02280955 (In German)].

2. Balfour GW, Stewart G. Case of enlarged spleen complicated with ascites, both depending upon varicose dilatation and thrombosis of the portal vein. J Med Edinburgh. 1869;14(7):589-99. PMID: 29639641

3. Rajani R, Björnsson E, Bergquist A, et al. The epidemiology and clinical features of portal vein thrombosis: a multicentre study. Aliment Pharmacol Ther. 2010;32(9):1154-62. doi:10.1111/j.13652036.2010.04454.x

4. Sarin SK, Philips CA, Kamath PS, et al. Toward a comprehensive new classification of portal vein thrombosis in patients with cirrhosis. Gastroenterology. 2016;151(4):574-577.e3. doi: 10.1053/j.gastro.2016.08.033

5. Tripodi A. Hemostasis in acute and chronic liver disease. Seminars in Liver Disease. 2017;37(1):28-32. doi: 10.1055/s-0036-1597770

6. Cool J, Rosenblatt R, Kumar S, et al. Portal vein thrombosis prevalence and associated mortality in cirrhosis in a nationally representative inpatient cohort. J Gastroenterol Hepatol. 2018;11(10); doi: 10.1111/jgh.14501 [Epub ahead of print]

7. Amitrano L, Guardascione MA, Brancaccio V, et al. Risk factors and clinical presentation of portal vein thrombosis in patients with liver cirrhosis. $J$ Hepatol. 2004;40(5):736-41. doi: 10.1016/j.jhep.2004.01.001

8. Ghabril M, Agarwal S, Lacerda M, et al. Portal vein thrombosis is a risk factor for poor early outcomes after liver transplantation. Transplantation. 2016;100(1):126-133. doi: 10.1097/TP.0000000000000785

9. De Franchis R, Abraldes JG, Bajaj J, et al. Expanding consensus in portal hypertension: report of the Baveno VI consensus workshop: stratifying risk and individualizing care for portal hypertension. $\mathrm{J} \mathrm{He}$ patol. 2015;63:743-752. doi: 10.1016/j.jhep.2015.07.001

10. Stine JG, Wang J, Shah PM, et al. Decreased portal vein velocity is predictive of the development of portal vein thrombosis: a matched case-control study. Liver Int. 2018;38(1):94-101. doi: 10.1111/liv.13500

11. Lankarani KB, Homayon K, Motevalli D, et al. Risk factors for portal vein thrombosis in patients with cirrhosis awaiting liver transplantation in Shiraz, Iran. Hepat Mon. 2015;15(12):2-5. doi: 10.5812/hepatmon.26407

12. Mangia A, Villani MR, Cappucci G, et al. Causes of portal venous thrombosis in cirrhotic patients: the role of genetic and acquired factors. Eur J Gastroenterol Hepatol. 2005;17(7):745-751. PMID: 15947552

13. EASL clinical practice guidelines: vascular diseases of the liver: $J \mathrm{He}$ patol. 2016;64(1):179-202. doi: 10.1016/j.jhep.2015.07.040
Khava B. Kodzoeva took part in the creation of the database, conducted statistical analysis, made the major contribution to the concept of the article and wrote the text of the article.

Vladimir T. Ivashkin made the major contribution to the concept of the article and approved the final version of the publication.

Kseniya A. Ulyanova, Sofia I. Rogacheva, Alina S. Volkova, Artem S. Dekhanov A.S. and Daria A. Strelkova D. took part in the creation of the database.

Financial support. The authors received no financial support for the research.

Conflict of interest. The authors have declared that no competing interests.

14. Ivashkin V.T., Mayevskaya M.V., Pavlov Ch.S. et al. Treatment of liver cirrhosis complications: clinical guidelines of the Russian scientific liver society and Russian gastroenterological association. Ross z gastroenterol gepatol koloproktol. 2016;26(4):71-102 (In Russ.).

15. EASL clinical practice guidelines for the management of patients with decompensated cirrhosis. J Hepatol. 2018;69(2):406-460. doi: 10.1016/j.jhep.2018.03.024

16. Russian society of surgeons [Electronic resource]. Clinical practice guidelines on the management of esophageal and gastric variceal bleeding. 2014. P.9. URL: http://общество-хирургов.pф/upload/gkk_iz_vven.doc, free (accessed 30.08.2018) (In Russ.)

17. Leonov V.P. Logistic regression in medicine and biology. [Electronic resource]. URL: http://www.biometrica.tomsk.ru/logit_1.htm http://www.biometrica.tomsk.ru/logit_8.htm, free (accessed 25.02. 2018) (In Russ.)

18. Stine JG, Shah NL, Argo CK, et al. Increased risk of portal vein thrombosis in patients with cirrhosis due to nonalcoholic steatohepatitis. $\mathrm{Li}$ ver Transplant. 2015;21(8):1016-1021. doi: 10.1002/1t.24134

19. Nonami T, Yokoyama I, Iwatsuki S, Starzl TE. The incidence of portal vein thrombosis at liver transplantation. Hepatology. 1992;16(5):1195-1198. doi: 10.1016/0270-9139(92)90014-Z

20. Merchante N, Rivero-Juárez A, Téllez F, et al. Liver stiffness predicts variceal bleeding in HIV/HCV-coinfected patients with compensated cirrhosis. AIDS. 2017;31(4):493-500. doi: 10.1097/QAD.0000000000001358

21. Huang L, Yu Q, Wang J. Association between changes in splanchnic hemodynamics and risk factors of portal venous system thrombosis after splenectomy with periesophagogastric devascularization. $\mathrm{Med} \mathrm{Sci}$ Monit. 2018;24:4355-4362. doi: 10.12659/MSM.909403

22. Piscaglia F, Gianstefani A, Ravaioli M, et al. Criteria for diagnosing benign portal vein thrombosis in the assessment of patients with cirrhosis and hepatocellular carcinoma for liver transplantation. Liver Transplant. 2010;16(5):658-667. doi: 10.1002/1t.22044

23. Arab JP, Martin-Mateos RM, Shah VH. Gut-liver axis, cirrhosis and portal hypertension: the chicken and the egg. Hepatol Int. 2018;12(S1):24-33. doi: 10.1007/s12072-017-9798-x

24. Carnevale R, Raparelli V, Nocella C, et al. Gut-derived endotoxin stimulates factor VIII secretion from endothelial cells. Implications for hypercoagulability in cirrhosis. J Hepatol. 2017;67(5):950-956. doi: 10.1016/j.jhep.2017.07.002

25. Azzawi YAl, Abboodi YAl, Fasullo M, Kheder J. Risk factors stratifications for portal venous thrombosis (PVT). J Liver. 2017;6(2):2-4. doi: 10.4172/2167-0889.1000208

26. Kurniawan A, Pratama HLN. Clostridium difficile infection is risk factor of portal vein thrombosis in hepatocellular carcinoma patients. Thromb Res. 2018;164:S215. doi: 10.1016/j.thromres.2018.02.076 
27. Moreau N, Wittebole X, Fleury Y, et al. Neutrophil-to-lymphocyte ratio predicts death in acute-on-chronic liver failure patients admitted to the intensive care unit. Shock. 2018;49(4):385-92. doi: 10.1097/SHK.0000000000000993

28. Sadequl ASSI, Rashid M, Alam M, et al. Thrombocytosis: a paraneoplastic syndrome in patients with hepatitis B related hepatocellular carcinoma. Gastroenterol Hepatol Int J. 2017;2(2):1-6. doi: 10.23880/GHIJ-16000121
29. Li Y, Qi X, Li H, et al. D-dimer level for predicting the in-hospital mortality in liver cirrhosis: a retrospective study. Exp Ther Med. 2017;13(1):285-289. doi: 10.3892/etm.2016.3930

30. Fletcher RH, Fletcher SW, Wagner EH. Clinical epidemiology: the essentials. 3rd ed. Williams \& Wilkins. 1996. P.91-100 